\title{
II. Meşrutiyet Dönemi Eğitim Sosyolojisi Öncülerine Göre Karakter Ĕgitiminde Öğretmenin Rolü ${ }^{1}$
}

\author{
Yahya AKYOL ${ }^{2}$ ve Baykal BİÇER ${ }^{3}$
}

Öz

Tarama modelinin kullanıldığı bu araştırmanın amac1, II. Meşrutiyet Dönemi'nde eğitimin sosyolojik yönü üzerinde duran eğitimcilerin karakter eğitiminde öğretmenin rolüne ilişkin görüşlerini incelemektir. Bu amaç doğrultusunda literatür ve uzman görüssleri çerçevesinde II. Meşrutiyet Dönemi'nde eserlerinde eğitimin sosyolojik yönünü vurguladıkları görülen 12 eğitimci araştırmaya dâhil edilmiştir. Araştırmada kullanılan verilerin toplanması doküman incelemesi yoluyla yapılmıştır. Toplanan veriler, betimsel analiz yaklaşımı kullanılarak çözümlenmiştir. Bu doğrultuda araştırmaya dâhil edilen eğitimcilerin eserleri, 2005 yılı Sosyal Bilgiler Dersi Öğretim Programi'nda yer alan 20 adet değer üzerinden değerlendirilmiştir. Araştırmaya sonuçlarına göre eğitimciler arasında karakter eğitiminde öğretmenin işlevini en çok vurgulayan eğitimcilerin İbrahim Alaettin Gövsa, Kazım Nami ve Sabri Cemil olduğu görülmüştür.

Anabtar Kelimeler: Karakter Eğitimi, II. Meşrutiyet Dönemi, Eğitim Sosyolojisi Öncüleri

\section{The Perspectives of the Pioneers of the Educational Sociology in the Second Constitutional Period about the Role of Teacher in Character Education}

\begin{abstract}
The purpose of this study is to investigate the perspectives of the educators who emphasized the sociology in the Second Constitutionalist period on the role of teacher in character education. In line with this objective, 12 educators that seemed to emphasize the sociology aspect of the education in their literary works in the Second Constitutionalist period were involved in the study in consideration of the literature and expert opinions. The general survey model was applied as the research method in the study. Furthermore, the collection of the data was performed by the analysis of the documents. The collected data were analyzed with the descriptive analysis approach. Accordingly, the literary works of the educators involved in the study were evaluated by the 20 -item value chart in the Curriculum of Elementary Social Sciences in 2005. The results of this study demonstrate that the educators who put emphasis primarily on the role of teacher in character education in the current study were Ibrahim Alaettin Gövsa, Kazım Nami and Sabri Cemil.
\end{abstract}

Key Words: Character Education, The Second Constitutionalist period, Educational Sociology Pioneers

Atıf İçin / Please Cite As:

Akyol, Y. ve Biçer, B. (2021). II. meşrutiyet dönemi eğitim sosyolojisi öncülerine göre karakter eğitiminde öğretmenin rolü. Manas Sosyal Arasttrmalar Dergisi, 10(1), 224-235.

Geliş Tarihi / Received Date: 03.11.2020

Kabul Tarihi / Accepted Date: 17.12.2020

\footnotetext{
${ }^{1}$ Bu makale Prof. Dr. Baykal BİÇER danışmanlı̆̆ında Yahya AKYOL tarafindan hazırlanan "II. Meşrutiyet Dönemi Eğitim Sosyolojisi Öncülerinin Karakter Eğitimine İlişkin Görüşlerinin İncelenmesi" adlı doktora tezinden üretilmiştir.

2 Dr. - Milli Eğitim Bakanlı̆̆1 Çiğli Şehit Şenali Ocak Ortaokulu, yahya_kyol@hotmail.com

(D) ORCID ID: 0000-0002-4844-6349

${ }^{3}$ Prof. Dr. - Kütahya Dumlupınar Üniversitesi Eğitim Fakültesi, baykal.bicer@dpu.edu.tr

(i) ORCID: 0000-0003-1494-6975
} 


\section{Giriş}

İnsanlığın doğuşundan bugüne bireyleri iyi bir insan olarak yetiştirmek, insan hayatını değerli hale getirmenin bir yolu olarak görülmüştür. Bunun için aile, okul ve çevre gibi sosyal kurumların karakter eğitimi vermesi gerektiği düşünülmüştür. Fakat bu kurumların karşısına savaşlar, ekonomik krizler, salgınlar ve teknolojik imkânların kötüye kullanımı gibi birçok ciddi sorun çıkmıştır (Ekşi, 2003, s.79). Bireyden bu sorunlarla baş ederken aynı zamanda sürekli olarak değişen ve gelişen dünya şartlarına uyum sağlaması ve kurulan toplumsal düzenin bir parçası olarak kendi üzerine düşen sorumlulukları yerine getirmesi de istenmiştir (Yükrük ve Akarsu, 2015, s. 1685).

Dünyanın farklı bölgelerinde yapılan araştırmalar, günümüzde vatan sevgisi, adalet, yardımseverlik, sayg1, sevgi v.b. değerlerin her geçen gün önemini kaybettiğini, buna paralel olarak sosyal, siyasi ve ekonomik sorunların temelinde ahlaki çöküntünün olduğunu göstermektedir. Öte yandan bu ahlaki çöküntünün etkilerinin azaltılması için eğitiminin önemli görevler üstlenebileceği düşünülmektedir (Sırrı ve Mehmedoğlu, 2015, s. 123). Ahlaki çöküş karşısında eğitimden beklenen şey, bireyleri çevresindeki kişilerle doğru bir şekilde iletişim kuran ve bir sorunla karşılaştığında bu sorunu etik yollardan çözmeye çalışan kişilere dönüştürmesidir. Bu dönüşümün gerçekleşmesini sağlayan uygulamaya ise karakter eğitimi denilmektedir (Gömleksiz ve Cüro, 2011, s. 97).

Milletler, varlıklarını sürdürebilmek için kültür öğelerini yeni nesillere aktarma ihtiyacı duyarlar. Kültür öğelerini yeni nesillere aktarmanın en iyi yolu eğitimdir. Bir milletin kültürünü oluşturan en önemli öğeler ise sayg1, dürüstlük, yardımseverlik, sorumluluk, çalışkanlık ve vatan sevgisi gibi değerlerin çevresinde şekillenen davranışlardır. Dolayısıyla bir millet için karakter eğitiminden yoksun bir eğitim düşünülemez. Öğrenciye aktarılan diğer akademik derslerde öğretilen bilgilerin bir anlam ifade edebilmesi için okulda karakter eğitiminin verilmesi önem arz etmektedir (Aydın, 2008, s. 9).

Karakter eğitimi, yeni yetişen nesillere temel insani değerlerin kazandırılması için bazı etkinlikleri ve yöntemleri uygulama çabasıdır (Ekşi, 2008, s. 119). Bireyin bu insani değerleri fark etmesi, anlaması, benimsemesi ve kendi kişiliğini bu değerlere göre şekillendirmesi de karakter eğitiminin kapsamına girmektedir (Ersoy ve Şahin, 2012, s. 1536). Bir birey, dünyaya geldiğinde iyiyi ve kötüyü ayırt edebilecek nitelikte değildir. $\mathrm{Bu}$ nedenle ailede, çevrede ve okulda aldığı eğitim oldukça önemlidir. Bu eğitim sayesinde, birey doğru ya da yanlış davranışlara yönelebilir. Bu noktada, bireye verilecek eğitimin niteliği önem kazanmaktadır (Montagu, 2000, s. 59).

Eğer yalnızca akademik başarı önemsenip bireyin bazı değerleri edinmesi önemsenmezse bu durum, kültürlenme süreci olarak da tanımlanan eğitimin karakter eğitimi yönünün eksik bırakıldığı anlamına gelir. Böyle bir eğitim akademik becerileri yüksek ama vatanseverlik, adalet, dürüstlük ve yardımseverlik gibi değerleri edinmemiş bireylerin ortaya çıkmasına neden olur. Bu tip bireyler de topluma yeterince fayda sağlamayabilir (Karatay, 2011, s. 1442).

Karakter eğitiminin başlangıç tarihinin Mezopotamya ve Mısır Uygarlıklarına kadar dayandığı görülmektedir. $\mathrm{Bu}$ uygarlıklardan sonra ortaya çıkan Antik Yunan uygarlı̆̆ında da öğrencilerden kahramanların erdemlerini öğrenmeleri ve bu erdemleri taklit etmeleri istendiği görülmektedir (Çam, 2016, s. 630). Ortaçağ'da ise erdemli olmanın en önemli şartı dindar olmaktı (Ülgen, 2010, s. 349). Bu dönemden sonra uzun süre karakter eğitimi farklı isimlerle anılmış olsa da, resmi olarak bu ifade, ilk kez Amerika'da 1700'lü yıllarda kullanılmıştır (Sırrı ve Mehmedoğlu, 2015, s. 126).

Bu dönemde karakter eğitiminde din eksenli bir ahlak eğitimi temel alınmıştır. Eğitim faaliyetleri, kilisenin ve ailenin kontrolüne bırakılırken kiliseye bağlı bireyler, kendi yaşam biçimlerini bu şekilde koruyabileceklerine inanmışlardır. Ancak zamanla nüfus hareketlerinden kaynaklanan çok kültürlülük gibi olgularla karakter eğitimi programlarının uygulanması gittikçe sürdürülemez olmuştur. Bunun sonucunda ise dürüstlük, insan sevgisi ve vatandaşlık gibi temel insani değerleri temel alan kitaplar yazıllp okulda kullanılmaya başlanmışıtır (Ekşi ve Katılmıs, 2011, s. 45).

1920'li yıllara gelindiğinde ise Amerika'daki kamu okullarında karakter eğitimi programlarına yoğun bir şekilde yer verilmeye başlandığı görülmektedir. 1930’larda karakter eğitimi programına dair yapılan bazı araştırmalarda, bu programın etkili olduğuna dair bir sonuç alınamadığ1 görülünce bu program gündemden düşmeye başlamıştır. Sonraki yıllarda toplumdaki bireyselleşmenin artması karakter eğitimine verilen önemin daha da azalmasına neden olmuştur. 1980'li ylllardan itibaren ise toplumdaki bozulmaya bağlı olarak yeniden popüler hale gelmeye başlamıştır. Temel insani değerlerin, toplumun içinde bulunduğu 
bunalımlardan kurtarabileceği düşünüldüğü için günümüzde de Batı toplumlarında karakter eğitimi önemini korumaktadır (Lickona, 1993, s. 7).

Türk tarihindeki karakter eğitimi uygulamalarının başlangıcının İslamiyet öncesi döneme kadar gittiği görülmektedir. İslamiyet öncesi dönemde töre adı altında gerçekleştirilen bu uygulamalar, İslamiyet kabul edildikten sonra ahlak adını almıs, sonraki süreçte ise kurulan her devletin eğitim programlarında din eksenli bir ahlak eğitimine yer verilmiştir (Akyüz, 2012, s. 11).

Selçuklular döneminde, Melikşah tarafindan Bağdat'ta kurulan Nizamiye Medresesi’nde bu medreseye baş müderris olarak atanan Gazali tarafindan İslam temelli, karakter eğitimi verilmiştir. Gazali, bu medresede çocukların iyi bir karaktere sahip olması için ahlak eğitimi konusunda bilgiler vermişti. Ona göre, karakter eğitimi, değerler hakkında doğru bilgilerin elde edilmesi ve bu değerlerin kazanılmasıyla mümkündür (Durakoğlu, 2014, s. 212).

Osmanlı döneminde ise medrese eğitimi incelendiğinde, karakter eğitimine din eksenli olarak yoğun şekilde yer verildiği görülmektedir (Şahin, 2012, s. 101). 1800’lü yıllarda toplumsal yapıdaki bozulmalar nedeniyle eğitim alanında pek çok yenilik ortaya konulmuştur. Özellikle II. Mahmut döneminde, karakter eğitimi alanında ortaya konulan en önemli yenilik ise Türkçe olarak okutulmaya başlanan ahlak dersleri olmuştur (Ekşi ve Katılmış, 2011, s. 58).

Eğitim alanında Batı karşısında oldukça geri kalındığının, okur-yazar oranının Batılı ülkelere kıyasla oldukça düşük olduğunun ciddi bir biçimde hissedildiği II. Meşrutiyet dönemine ise, verimli bir karakter eğitiminden söz etmek zordur (Tural, 2007, s. 178). Bu dönemde eğitimciler, ülkenin kötü gidişini durdurabilmek için var olan ahlak derslerinin gözden geçirilmesi gerektiği görüşünü dile getirmeye başladılar. Özellikle karakter eğitimi ile ilişkilendirilebilen derslerde vatanseverlik ve çalışkanlık değerleri ile ilgili uygulamaların yetersizliği üzerinde durdukları görülmüştür (Duran, 2017, s. 69). Bu eksikliğin giderilmesinde en büyük görevin öğretmenlere düştüğ̈̈ne inanan eğitimciler, çökmekte olan devleti okul ve öğretmenler kurtaracak algisına sahiptiler (Türker, 2008, s. 14). II. Meşrutiyet döneminde eğitim bakanlı̆̆ının da bu eksikliği fark ederek öğretmen yetiştirme politikalarına önem verdiği görülmektedir. Ayrıca öğretmenin niteliği ve öğretmen açığının giderilmesi bu dönemin önemli tartışma konularından biri olmuştur (Şahin ve Tokdemir, 2011, s. 860). Bu bağlamda araştırmanın amacı, II. Meşrutiyet Dönemi eğitimcilerinin karakter eğitiminde öğretmenin rolü hakkındaki fikirlerini tespit etmektir.

\section{Yöntem}

II. Meşrutiyet Dönemi eğitimcilerinin karakter eğitiminde öğretmenin rolü hakkındaki fikirlerini tespit etmeyi amaçlayan bu araştırma tarama modelindedir. Tarama modelinde araştırmacı, ortaya çıkan verileri değiştirme veya etkileme çabası içinde olmaz. Bu modelin kullanıldığı araştırmalarda ortaya çıkan bulguların üzerinde bir değişiklik yapılmadan okuyucuya sunulması gerekmektedir (Şimşek ve Yıldırım, 2018, s. 217). II. Meşrutiyet Dönemi'ndeki eğitimcilerin karakter eğitiminde öğretmenin rolü hakkındaki görüşlerinin ortaya çıkarılmaya çalışıldığı bu çalışmada var olan durum olduğu haliyle ortaya çıkarılmaya çalışıldığ1 için tarama modeli kullanılmışır.

\section{Araştırmanın Kapsamı}

Araştırmanın kapsamını II. Meşrutiyet Dönemi'nde eğitimin sosyolojik yönü üzerinde duran eğitimciler oluşturmaktadır. Araştırma kapsamına dâhil edilen eğitimcilerin seçiminde, Türk Sosyoloji Tarihi hakkında zengin bir içeriğge sahip olan Hilmi Ziya ÜLKEN'in Türkiye'de Cağdas Düşünce Taribi adlı kitabından faydalanılmış, ayrıca Yahya AKYÜZ'ün Türk Eğitim Tarihi adlı kitabı da incelenerek bu eğitimcilerin II. Meşrutiyet Dönemi'nde eğitimin toplumsal yönünü vurgulayan eğitimciler oldukları teyit edilmiştir. Literatüre ek olarak araştırma kapsamına dâhil edilen eğitimcilerin seçiminde uzman görüşü alınmış ve II. Meşrutiyet Döneminde eserlerinde eğitimin sosyolojik yönünü vurguladıkları görülen 12 eğitimci (Emrullah Efendi, Ethem Nejat, Halil Fikeret Kanat, Alaettin Göusa, İsmail Hakker Baltacioğlu, Kazrm Nami, Nafi Atuf, Prens Sabahattin, Sabri Cemil, Satı Bey, Şemsettin Günaltay, Ziya Gökalp) araştırmaya dâhil edilmiştir. Araştırmaya dâhil edilen eğitimcilerin eserleri, 2005 yllında Sosyal Bilgiler Dersi Öğretim Programi'nda yer alan 20 adet değer üzerinden değerlendirilmiştir.

\section{Verilerin Toplanması ve Analizi}

Verilerin toplanması, doküman incelemesi yöntemi kullanılarak yapılmıştır. Çeşitli materyallerin analizinde kullanılan doküman incelemesi, sosyal bilimleri ilgilendiren hemen hemen her konunun araştırılmasında kullanılmaktadır. Fakat doküman incelemesinin en yoğun kullanıldığı alan tarihi 
araştırmalardır. Çünkü geçmişte yaşanmış durumları veya olayları başka bir şekilde incelemeye imkân yoktur (Karasar, 2009, s. 183). Yapılan bu çalışmada ise tarihi bir döneme tanıklık etmiş eğitimcilerin karakter eğitimi hakkındaki görüşleri ortaya çıkarılmaya çalışıldığı için verilerin toplanmasında doküman incelemesi tercih edilmiştir.

Araştırma kapsamında karakter eğitimine ilişkin çeşitli yazıları olan ve eserlerinde sosyolojik problemlerin çözümünü eğitimde gören 12 eğitimcinin ulaşılabilen eserleri 20 adet değer üzerinden incelenmiştir. Yapılan doküman incelemesinde analiz birimi olarak "sözcük" kabul edilmiştir. Doküman incelemesi ile elde edilen veriler, betimsel analiz yaklaşımı kullanılarak çözümlenmiştir. Betimsel analizde amaç toplanan verileri düzenleyerek ve yorumlayarak okuyucuya sunmaktır. Bu amaçla toplanan veriler, sistematik ve açık bir biçimde betimlenmiş, sonra yapılan bu betimlemeler, yorumlanmış ve bulgular başlğ̆ altında sunulmuş olan birtakım sonuçlara ulaşılmıştır. Bununla birlikte çalışmada, betimsel analiz yaklaşımına uygun olarak Milli Eğitim Bakanlığının 2005 yllında yayımlanan Sosyal Bilgiler Öğretim Programı'nda yer verdiği 20 adet değer, analiz için kullanılmıştır.

\section{Bulgular}

II. Meşrutiyet Dönemindeki eğitimcilerin karakter eğitiminde öğretmenin rolü hakkındaki görüşlerinin öncelikle frekansları tespit edilerek tablo halinde sunulmuş, arkasından bu eğitimcilerin doğrudan görüsslerine yer verilmiştir. II. Meşrutiyet Dönemi eğitimcilerinin karakter eğitiminde öğretmenin rolüne ilişkin görüşlerinin dağılımı Tablo 1'de sunulmuştur.

Tablo 1. Ë̆gitimcilerin Öğretmenin İslevine İlişkin Görüslerinin Dağgllmı

\begin{tabular}{|c|c|c|c|c|c|c|c|c|c|c|c|c|c|}
\hline Öğretmenin işlevi & 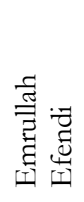 & 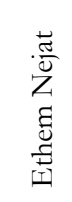 & 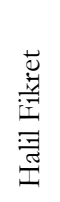 & 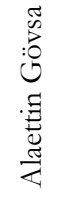 & 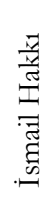 & 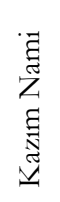 & 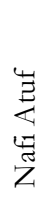 & 莺 & 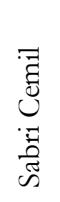 & 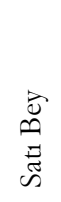 & 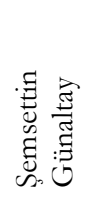 & 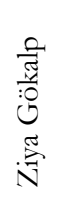 & $\frac{\text { E }}{\text { है }}$ \\
\hline Çalışkanlık & 1 & 3 & 3 & 6 & 1 & 7 & 2 & 1 & 9 & 6 & - & 1 & 40 \\
\hline Sorumluluk & - & - & 1 & 1 & 4 & 3 & 1 & 1 & 3 & 1 & - & 3 & 18 \\
\hline Vatanseverlik & 1 & - & 1 & 3 & 3 & 1 & - & - & 2 & 2 & - & 3 & 16 \\
\hline Özgürlük & - & 1 & 1 & 2 & 2 & 2 & - & - & 2 & - & - & - & 10 \\
\hline Dürüstlük & - & - & 1 & 8 & - & - & - & - & - & - & - & - & 9 \\
\hline Bilimsellik & - & - & 2 & - & - & 2 & - & - & - & 2 & - & 2 & 8 \\
\hline Sayg1 & - & - & - & - & 2 & 2 & 1 & - & 1 & - & - & - & 6 \\
\hline Dayanışma & - & - & - & - & 2 & 3 & - & - & - & - & - & - & 5 \\
\hline Sağlıklı Olmaya Önem Verme & - & 1 & - & 2 & - & - & - & - & 1 & - & - & - & 4 \\
\hline Adil Olma & 1 & - & 1 & - & - & - & - & - & 2 & - & - & - & 4 \\
\hline Sevgi & - & - & - & 1 & - & - & 1 & - & - & - & - & - & 2 \\
\hline Yardımseverlik & - & - & 2 & - & - & - & - & - & - & - & - & - & 2 \\
\hline Hoşgörü & - & - & - & - & - & 2 & - & - & - & - & - & - & 2 \\
\hline Aile Birliğine Önem Verme & 1 & - & - & - & - & - & - & - & - & - & - & - & 1 \\
\hline Barış & - & - & - & - & - & - & - & - & - & - & - & - & - \\
\hline Bağımsızlık & - & - & - & - & - & - & - & - & - & - & - & - & - \\
\hline Duyarlılık & - & - & - & - & - & - & - & - & - & - & - & - & - \\
\hline Estetik & - & - & - & - & - & - & - & - & - & - & - & - & - \\
\hline Misafirperverlik & - & - & - & - & - & - & - & - & - & - & - & - & - \\
\hline Temizlik & - & - & - & - & - & - & - & - & - & - & - & - & - \\
\hline Toplam & 4 & 5 & 12 & 23 & 14 & 22 & 5 & 2 & 20 & 11 & - & 9 & 127 \\
\hline
\end{tabular}


Tablo 1'de çalışma grubundaki eğitimcilerin, öğretmenin işlevine ilişkin görüşleri incelendiğinde, bu eğitimcilerin yazdıkları metinlerde öğretmenin işlevine ait toplam $\mathrm{f}=127$ bulgunun yer aldığı görülmektedir. Tablo 1'de verilen II. Meşrutiyet dönemi eğitimcilerinin karakter eğitiminde öğretmenin işlevine ilişkin görüşlerinin frekans dağılımı incelendiğinde, İbrahim Alaettin Gövsa $f=23$, Kazım Nami $f=21$, Sabri Cemil $\mathrm{f}=20$, İsmail Hakkı Baltacıŏlu $f=14$, Halil Fikret Kanat $f=12$, Satı Bey $f=11$,Ziya Gökalp $f=9$, Ethem Nejat $f=5$, Nafi Atuf $f=5$, Emrullah Efendi $f=4$ ve Prens Sabahattin $f=2$ şeklinde siralandiğ1 görülmektedir.

Tablo 1'de verilen II. Meşrutiyet dönemi eğitimcilerinin karakter eğitiminde öğretmenin işleviyle ilişkilendirdikleri değerlerin dağılımı incelendiğinde, çalışkanlık $f=40$, sorumluluk $f=18$, vatanseverlik $f=16$, özgürlük $f=10$, dürüstlük $f=9$, bilimsellik $f=8$, saygı $f=6$, dayanışma $f=5$, să̆lıklı olmaya önem verme $f=4$, adil olma $f=4$, sevgi $f=2$, yardımseverlik $f=2$, hoşgörü $f=2$ ve aile birliğine önem verme $f=1$ şeklinde sıralandığı görülmektedir.

II. Meşrutiyet dönemi eğitimcilerin çeşitli eserlerinde yer alan ve Tablo 1'de de verilen karakter eğitiminde öğretmenin işlevlerine dair bazı görüşler rastgele seçilmiş, bu işlevlere yönelik ifadeleri aşağıda sunulmuştur.

\section{Çalışkanlık}

II. Meşrutiyet Dönemi eğitimcileri, Osmanlı Devleti'nin güç kaybetmesinde eğitimin büyük bir rolü olduğunu düşünmüşlerdir. Bu nedenle Batı'daki güçlü devletlerde ve Osmanll Devleti'nden ayrılan gayrimüslim unsurlarda uygulanan eğitim politikalarıyla Osmanlı Devleti'nde uygulanmakta olan eğitim politikalarını sık sık kıyaslamışlardır. Bu kıyaslamayı yapan eğitimcilerden biri Ethem Nejat'tır. Ona göre Osmanlı'daki eğitim bireyleri iş yapma konusunda heveslendirmekten ve çalışanlık bilincini geliştirmekten yoksundur. Bu durumun düzeltilmesinde en büyük görevin öğretmenlere düştüğünü düşünen Ethem Nejat, Türklük Nedir ve Terbiye Yollar adlı kitabında şu ifadeleri kullanmıştır: "Mürşit muallim olmalıdır. Köylünün, işçinin, çiftçinin çocuğunu karanlıktan ve hurafelerden, batıl inançlardan kurtarıp hayat adamı, çalışkan, yaşadığı çevrenin ekonomik gücü hakkında bilgi sahibi bireyler olarak yetiştirebilsin." (Öztürk, 2001, s. 30). Halil Fikret Kanat ise Hayat Mecmuası'nda yazdığı Genclike Terbiyesinde Rubi Esaslar adlı yazısında ise gençlerin ruhsal durumları gereği hiçbir işe uzun süre odaklanamadıklarını belirtip öğretmenlerin iş hevesi ve yapılan işte sebat gösterme konusunda öğrencilere rol model olaması gerektiğini vurgulamışır (Kanat, 1928, s. 4).

İbrahim Alaettin Gövsa'ya göre, çocuğun psikolojik ya da fiziksel durumu onun eğitimi üzerinde büyük bir etkiye sahiptir. Dolayısıyla öğretmenler, çocuklara çalışkanlık bilinci kazandırırken bu durumu göz önünde bulundurmalıdır. Bu duruma dikkat edilmediğinde fiziksel rahatsızlı̆̆ olan bir öğrenci yanlışkla tembel bir öğrenci olarak düşünülebilir. Gövsa, Rubiyat ve Terbiye adlı kitabında bu konudaki düşüncelerini şu sözlerle dile getirmiştir: "Kulak veya gözlerindeki arızadan haberdar olamadıkları veya bu ciheti hiç düşünemedikleri için keyfiyeti muallime de haber vermezler. Muallim diğer çocukların anladıkları bahisleri onların takip edememiş ve öğrenememiş olduklarını görerek bu çocukları tembel veya dikkatsiz yahut kabiliyetsiz addederler."(Gövsa, 1929, s. 22).

Muallimin Meslek Ablâkı adlı kitabında öğretmenlik kavramının ne olduğunu açıklamaya çalışan Kazım Nami'ye göre öğretmenlik, uzun bir çalısma dönemi sonrasında elde edilen bir makamdır. Bu nedenle öğrencilere çalışkanlık bilincini kazandırmak isteyen bir öğretmenin öncelikle kendisinin bu konuda model olması gerekmektedir (Nami, 1934, s. 1). Nafi Atuf, Sa’y ve Tetebbu dergisinde yazdığ1 Mektep Terbiyesi adlı yazıda ögrretmenlerin sınıf yönetiminde yaptığı hataların öğrencilerin çalısma heveslerini köreltebildiğinden bahsetmiştir. Öğrencileri sınıfta kontrol etmek adına yapılan aşırı baskıların öğrencilerdeki faaliyet arzusunu azaltabileceğini ifade etmiştir (Atuf, 1911, s. 8).

Sabri Cemil, de Yeni Mektep dergisinde yazdığı Az ve İyi adlı yazıda öğrencilerdeki tembelliğin nedenlerinin araştırılması gerektiğini belirtmiştir. Ona göre ceza vererek çocukların tembelliği engellenemez: "Yine kabahati çocukta buluruz. Tembelliğe merhem sürmek üzere ceza, ceza üstüne veririz. Hiçbir fark, hiçbir terakki görülmez. Bu şakirdin artık sslah kabul etmez bir tabiatta olduğuna kanaat getiririz. Meyus oluruz. Fakat insaf edelim. Çocuk neden dersi öğrenmedi, sebebini araştıralım." (Cemil, 1911, s. 113). Satı Bey, Layihalarm adlı kitabında öğretmenlerdeki ilerleme ve yükselme umudunun öğrencilerin çalışkanlığı üzerinde etkili olduğunu şu sözlerle açıklamıştır: "Muallimlik mesleğinde terakki ve teali ümidi olmadıkça, yetişecek muallimlerdeki gayret ve faaliyetin az müddet zarfinda intıfasına mani olmak mümkün olamayacağı müstağni-i izah ve isbat bir hakikattir." (Sat1, 1910, s. 21). 


\section{Sorumluluk}

Halil Fikret Kanat, Muasır Terbiye Ülküleri ve Terbiyede Yenilikler adlı kitabında çocuktaki sorumluluk hissinin özgürlük anlayışı ile birlikte geliştiğini belirtmiştir (Kanat, 1934, s. 72). İbrahim Alaettin Gövsa ise Rubiyat ve Terbiye adlı kitabında öğretmenlere sorumluluk eğitimi üzerine şu tavsiyelerde bulunmuştur: "Çocuklarda mesuliyet endişesi daima müteyakkız bulundurunuz! Sınıfta bir vazifenin ifa edilmemesi umumi bir hayret uyandırmalıdır. Bu da muallimin takipçi olması ile olur. Talebede mesuliyet fikrinin yerleşmesi hususunda ceza ve mükâfattan ziyade müessesenin itiyatları ve muallimin seciye ve şahsiyeti müessirdir (Gövsa, 1929, s. 123).

Mürebbilere adlı kitabında İsmail Hakkı Baltacıŏlu, sorumluluk eğitimi ile çocuğun odası arasındaki ilişkiye dikkat çekmiştir: "Hâlbuki çocukta şahsiyetin teşekkülü, haysiyetin, mesuliyetin vücuda gelmesi hatıra gelmeyen basit vasıtalarla oluyor. Bence oyundan daha mühim olan şey çocuğun odasıdır. Çocuk ne küçülmüş bir adam, ne de büyük adamın ufak bir numunesidir. O, nevi kendisine münhasır bir mevcuttur." (Baltacıŏlu, 1932, s. 204). Sabri Cemil ise Yeni Mektep dergisinde yazdığ1 Ameli Olalım adlı yazıda eğitimin amaçlarından birinin de sorumluluk sahibi bireyler yetiştirmek olduğunu dile getirmiştir:" Ahlâkı nasıl bi'l-amel okutmalı? Çocukların iyi huylu olmasını, iyi iş yapmaları için istemez miyiz? O halde onların kalplerine temas etmek, kendilerinde hak, hayır, vazife fikirlerini uyandırmak iktiza eder." (Cemil, 1911, s. 66).

Yeni Mektep dergisinde yazdığ1 Cocukta Mesuliyet Fikeri adlı yazıda ise sorumluluk eğitimi verilirken k1sa süre içinde sonuç almayı beklemenin yanlış olduğunu belirtmiştir: "Genç bir çocuğun mesuliyeti pek mahduttur mesuliyet yavaş yavaş zâhir olur. Bunun için çocuktan kendi hareketini anlaması birden değil, tedricî bir surette istenmelidir. Ahlaki mesuliyeti mücerret malumat ile telkin etmek mümkün değildir." (Cemil, 1912, s. 321). Satı Bey ise karakter eğitiminin en önemli amacının çocuklara sorumluluk ve görev bilinci kazandırmak olduğunu belirtmiştir. Fenni Terbiye adlı kitabında şu düşüncelere yer vermiştir: "Hubb-i fezailin esası his-ü vazifeve fikri mesuliyettir. Onun için etfalde hiss-i vazife uyandırmaya, onlara hiss-i mesuliyet vermeye çalışmak da lazımdır. Bu terbiye-i ahlakiyenin en mühim gayesidir." (Satı, 1911, s. 125).

\section{Vatanseverlik}

İbrahim Alaettin Gövsa'ya göre bilinmeyen şeylerin sevgisi de sahte olur. Bu nedenle ilkokul çağı̆ndan itibaren çocuklara vatanın tarihini ve coğrafyasını çok iyi kavratmak gerekir. Bu işi yaparken çocuklara milletimizin yaşadığı tarihi zaferleri ve felâketleri hatırlatmak gerekir. Aynı zamanda milletimizin insanlık tarihine yaptı̆̆ hizmetler ve milletimizin içinden çıkan büyük insanların hayatları ve kişilikleri de çocuklara anlatılmalıdır (Gövsa, 1929, s. 93).

Baltacıoğlu, Talim ve Terbiyede Inkezlap adlı kitabında bireylerde vatanseverlik fikrinin oluşabilmesi için erken yaşlarda vatanseverlik eğitimine başlanması gerektiğini belirtmiştir: "Bir insan düşününüz ki yine hayatın ilk devirlerinde vatan duygusu nedir duymamıs, bilmemiş; böyle bir adamda vatan sevgisi nasıl yaşar?" (Baltacıoğlu, 1995, s. 42). Baltacıoğlu'na göre tarih, coğrafya ve güncel olaylara dair bilgiler verilen öğrencilerde vatana karşı sayg1, sevgi ve bağlllıkta bir samimiyet gözlenebilir. Baltacıŏ̆lu, bu konudaki düşüncelerini Toplu Tedris adlı kitabında şu şekilde aktarmaktadır: "Bu bilgileri artırmak için onlarda devamlı alâkalar uyandırmak ve bunun neticesi olarak talebe yurda, ulusa karşı sevgi, sayg1, bağl1lık ve hizmet aşkı aşılamak, milli meselelere karşı kendilerinde azami derecede hassasiyet ve alâka uyandırmak gerekir." (Baltacıŏglu, 1938, s. 8).

Kazım Nami, Muallimin Meslek. Ablâkı adlı kitabında çocuklara vatan sevgisi aşılanmasında öğretmene büyük bir görev düştüğünü belirtmiştir: "Öğretmen işinin ne kadar önemli olduğunun farkında olmalıdır çünkü ona emanet edilecek çocuklar yarının büyükleridir. Görevinin farkında olmayan bir öğretmenin elinde yetişen çocuklar gelecekteki görevlerini okulda öğrenmeyerek, yurt sevgisini okulda almayarak hem kendileri için hem de Türk yurdu için faydasız yurttaşlar olurlar." (Nami,1934, s. 27). Sabri Cemil, vatanın ne olduğunun halka anlatılmasında öğretmene büyük görevler düştüğünü belirtmektedir. Yeni Mektep dergisinde yazdığı İlk Muallim Kafilesi adlı yazısında özellikle kırsal kesimdeki halka doğru yolu gösterebilecek olan tek kişinin öğretmen olduğunu, bu bağlamda kirsal kesimdeki öğretmenlerin halka vatan sevgisini anlatma konusunda yüklerinin ağır olduğunu vurgulamıştır (Cemil, 1911, s. 97).

\section{Özgürlük}

Uygulamalı derslerin çocuklara özgür ortam sağlamaya daha müsait dersler olduğunu belirten Gövsa, Rubiyat ve Terbiye adlı kitabında bu düşüncelerini şu şekilde açıklamıştır: "Oyunlarda, elişlerinde, resim, 
kitabet, hesap vazifelerinin hazırlanmasında çocuklara mümkün olduğu kadar hürriyet vermeliyiz ki yalnız mihaniki faaliyetler yapmaya ve ancak gördüklerini tekrar etmeye münhasır kalmasınlar ve bizzat muhakeme edip bulduklarını da tatbik etsinler." (Gövsa, 1929, s.57). Gövsa'ya göre sınıf ortamında itaat ve özgürlük arasında bir denge kurulması gerekmektedir: "Hürriyetkâr terbiyede ise çocuğun hürriyet hakkının tecavüzden masun olduğu addolunur. Hatta muallimin terbiye ve talim için onun temayüllerinden istifade etmesi lazım görülür. Şu halde çocuğu itaat vasıtası ile hürriyete hazırlanmalı ve itaati hürriyet içinde, yani tabii olarak temin etmelidir." (Gövsa, 1929, s. 79).

Karakter eğitiminin de özgürlükçü bir anlayışla gerçekleştirilmesi gerektiğini belirten Baltacıoğlu, bunun gerçekleşmesi durumunda çocuğun kendi sorumluluklarının farkına varan bir bireye dönüşeceğini dile getirmiştir: "Ahlak terbiyesi, çocuğun hürriyetini kısıtlamak, onu başkalarının emriyle haraket eden bir makine haline getirmek değil; çocuğu vicdanının oluşumuna hizmet edecek hürriyete kavuşturmak, çocuktan kendi sorumluluğunu kendi ölçer bir şahsiyet meydana getirmektir. Hürriyet, bütün ahlâk terbiyesinin en sağlam dayanak noktasıdır." (Baltacıoğlu, 1995, s. 45).

Nami, Terbiyevi Yaz̧lar adlı kitabında eğitimde özgürlükçü bir anlayışın öneminden bahsetmiştir: "Kızını dövmeyen dizini döver, meseli ruhlarımızda henüz bütün kuvvetiyle yaşıyor. Ve vatandaşların hür terbiye ile yetiştirileceğini anliyamıyoruz. İnzibat ruhu sultavi bir terbiyeden ziyade hür bir terbiyenin eseridir." (Nami, 1932, s. 39).

Cemil (1911, s. 15), Yeni Mektep dergisinde yazdı̆̆ Mekteplerimizde Meskenet ve Çare-i İzalesi adlı yazıda ise öğrencilere verilen özgürlügün bir sınırı olduğunu dile getirmiştir: "Her halde şunu bilmeli ki serbestlik demek, arsızlık demek değildir. Çocuklara serbestî verilmesi kendilerinin yaramazlık yapmalarına müsait olunmayı müstelzim olmaz. Bilakis serbestlik muallime iyi bir zemin-i terbiye hazırlar. Çocukta baş gösteren fena huylar, fena temayüller muzır otlar gibi çıkarılmalıdır."

\section{Dürüstlük}

Gövsa (1929, s. 98), Ruhiyat ve Terbiye adlı kitabının bir başka bölümünde ise çocuklarda gerçekçiliğe ve dürüstlüğe karşı bir ilgi oluşturmak gerektiğini belirtmiştir: "Çocuklara hakikat aşkını, fikir iffetini telkine çalışınız! Abartmalara müsaade etmeyiniz! İnsanın kendi nefsi ile yüzleşmesindeki hazzı çocuklar kavrayabilirler. Bu ahlâki hazzı onlara telkin ediniz." Gövsa'ya göre dürüstlük eğitimi verilen çocuklara şeref ve haysiyet kavramlarının anlamları çok iyi bir şekilde öğretilmelidir. Bu kavramların öğretimi öğretmene eğitim sırasında faydalı olabilir: "Çocuğun izzet-i nefsini terbiyede bir yardımcı olarak kullanınız! Çocuğun izzet-i nefsine riayet edenler muhabbetini kazanırlar. Bu kazanç mürebbi için kuvvet temin eder. Fena temayüllere, yalan vesaire gibi tezahürlere çocuğun izzet-i nefsi ile galebe çalmak mümkündür." (Gövsa, 1929, s. 80). Gövsa’nın vurguladığı bir diğer konu ise öğretmenin dürüstlük konusunda çocuklara rol model olması gerektiğidir: "Doğruluk hissini verebilmek için mürebbilerin ilk vaziyetleri çocuklara yalan numunesi vermemektir. Binaenaleyh çocuğun dürüst ve samimi olmasını istiyorsanız siz bizzat buna misal olunuz." (Gövsa, 1929, s. 98).

\section{Bilimsellik}

Nami, Muallimin Meslek. Ablâkı adlı kitabında okulun amacını açıklamaya çalışmıştı. Ona göre okul, kendini geleceğe göre hazırlamış, bilime önem veren, verimli çalışan, vatansever ve fedakâr bireyler yetiştiren bir kurum olmalıdır. Kısacası çocukları o kapalı yapılara toplayıp onları arzu ettikleri yaşayıștan mahrum etmedeki amaç onlara yalnızca okuma yazma öğretmek değildir (Nami, 1934, s. 5). Ziya Gökalp, Hars ve Medeniyet adlı kitabında, insanların hayatlarını bilimsel incelemelere ayırmaya ve çalışmaya vermeleri için hırslı bir inanca ihtiyaç duyduklarını dile getirmiştir. Ona göre bir insanın kalbinde aşk bulunmazsa, hayatını zorluklara gögüs germeye terk etmez. Tembellikten vazgeçemez. Rahat yaşamak ister (Gökalp, 2012, s. 61).

\section{Sayg1}

Nami (1916, s. 809), Muallim dergisinde yazdığı Cocukluğu Sevmek adlı yazıda ise çocuğun öğretmene duyduğu saygı üzerinde durmuş, bu saygının gerçekleşmesi için öncelikle öğretmenin çocuğa kendini sevdirmesi gerektiğini dile getirmiştir:" Çocuklar, muallimin gönülden muhabbetini hissederlerse çatık kaşlılığa, asabiyete de hürmet ederler." Pedagoji Önünde Gari adlı kitabında da benzer düşünceleri ortaya koyan Nami, öğretmenin cezalandırma yöntemleri ile kendisine saygı duyulmasını sağlayamayacağını ifade etmiştir: "Demek muallim; aciz, görgüsüz, bilgisiz olursa zorla, ceza ile çocuklara hürmet, itaat hissini veremez. Çocuk mualliminin her türlü manevi faziletlerine, okuttuğu derslerdeki derin vukufuna itimat 
hasıl ettikten sonra, ona karşı tamamıyla yürekten gelen bir hürmet, bir itaat duygusu besler.” (Nami, 1928, s. 4).

Cemil, Yeni Mektep dergisinde yazdığı Mekteplerimizde Meskenet Çâre-i İzâlesi adlı yazıda ise öğrencinin öğretmene sayg1 duymasında öğretmenlerin alan bilgisinin etkili olduğunu ifade etmiştir: "İsteriz ki talebemiz bizi dinlesin, bize hürmet etsin. Acaba tekdir, tehdit, ceza şu gayeye hâdim olabilir mi? Matlûb inzibatı temin edebilir mi? Daha nâfî bir usul-i inzibat vardır. O da dersleri dikkatle hazırlayarak misallerle, hikâyelerle, fikri ikaz ve merakı tahrik eden şu tatlı boyalarla tezyîn ederek cazibedâr kılmaktır." (Cemil, 1911, s. 12).

\section{Sağlıklı Olmaya Önem Verme}

Ethem Nejat, medreseden mezun olan bir hocanın aynı zamanda insan sağllğı konusunda uzman olması gerektiğini ifade etmiştir: "Mürşit tabib olmalıdır; köylülerde çoğunlukla rastlanan hastalıklara sıtmaya, sarıllğa, frengiye, vereme, çelimsizliğe, kansızlı̆̆a bir son verip yemeyi içmeyi ve beden terbiyesini öğretmelidir. Hastaları tedavi edip ilacını vermelidir." (Öztürk, 2001, s. 30).

Gövsa (1929, s. 4) ise Rubiyat ve Terbiye adlı kitabında yeni yetişecek nesillere düzenli spor yapmanın önemini kavratmak gerektiğini, sağlıklı nesiller yetiştirmek bu durumun elzem olduğunu dile getirmiştir: "Çocukları beden itibariyle mükemmel bir hale koymak lazımdır. Bunun için sıhhatlerine itina etmek, onlara sıhhat kaidelerine uygun itiyatlar vermek, yine fenni esaslara uygun olmak şartılla çocukları jimnastikle ve sporla ülfet ettirmek, bu suretle vücutlarının sıhhatini temin etmek icap eder.” Aynı kitabın bir başka bölümünde ise köylüye sağlıklı olmanın önemini anlatmanın köy öğretmenlerinin görevlerinden biri olduğunu belirtmiştir: "Köylünün sıhhati ve fena âdetlerin zararları hakkında çok esaslı ve kuvvetli telkinler yapmak köy mualliminin zekâ ve vicdanında daima canlı ve daima ateşli bir halde bulunması elzem olan bir gayedir." (Gövsa, 1929, s. 5).

\section{Yardımseverlik}

Halil Fikret Kanat, Düş̈̈nce dergisinde yazdığı Terbiyenin Dâhili Teşkilatı Hakekında Nazariyeler adlı yazıda Pestalozzi'nin yardımseverlik yönünü öğretmenlere örnek olarak göstermiştir:” Pestalozzi, yalnız ve yalnız fakir çocuklarla uğraşmak, onlara babalık etmek, onların deruni kuvvetlerini inkişaf ettirmek, hayatı kazanabilmelerine yardım etmek için kendisine teklif edilen büyük memuriyetleri dahi reddetmekten çekinmemiştir." (Kanat, 1922, s. 50). Muasir Terbiye Ülkëlleri ve Terbiyede Yenilikler adlı kitabında da Pestalozzi'nin çalışmalarından bahseden Kanat, onun yardımseverlik eğitimini nasıl verdiğini açıklamıştır:" Pestalozzi, Stans şehrinde fakir çocuklarla uğraşırken grup halinde terbiyeye ehemmiyet veriyor, küçük çocukları büyük çocukların yardımı ile yetiştirmeye çalışıordu. Bu sayede Pestalozzi çocuklarda içtimai hisleri inkişaf ettirmek ve cemaat hayatı için çocukları daha iyi hazırlamanın mümkün olduğunu keşfetmişti." (Kanat, 1934, s. 8).

\section{Tartışma, Sonuç ve Öneriler}

II. Meşrutiyet Dönemi'nde eğitimim toplumsal yönünü öne çıaran eğitimcilerin arasında karakter eğitiminde öğretmenin işlevini en çok vurgulayan eğitimcilerin İbrahim Alaettin Gövsa, Kazım Nami ve Sabri Cemil olduğu görülmüştür. Öğretmenin işlevine en sık değinen eğitimci ise İbrahim Alaettin Gövsa olmuştur. Gövsa, öğretmenin bir çocuk hakkında bir karara varmadan önce onu çok iyi tetkik etmesi gerektiğini dile getirmiştir. Araştırmanın bu bulgusu Karagöz ve Duman'ın (2014, s. 586) 1908-1928 yıllar arası süreli yayınlarda yer alan eğitim görüslleri ve öneriler adlı çalışmasındaki bulgular ile kısmen örtüşmektedir. $\mathrm{Bu}$ araştırmada Gövsa'nın öğrencilerdeki dikkat eksikliği konusunda bazı görüşler ileri sürdüğü ve engelli öğrenciler ile ilgili dikkate değer bir akademik çalışmanın yapılmamasından yakındığı dile getirilmiştir.

II. Meşrutiyet Dönemi eğitimcilerine göre karakter eğitiminde başat rol öğretmene düşmektedir. Bu dönemde, öğretmen her şeydir fikrinin hâkim olduğu görülmektedir. Öğretmenin eğitimde tek kaynak olarak görülmesi halkın ancak bu yolla cahillikten kurtulabileceği düşüncesi mevcuttur. Bu bulgular, Türker’in (2008, s. 14) II. Meşrutiyet devri eğitim hareketleri ve günümüze yansımalar adlı çalışmasındaki bulgular ile örtüşmektedir. Türker, bu dönemde "Çökmekte olan devleti okul ve ögretmenler kurtaracaktur." şeklinde bir algının hakim olduğunu ve bu algı neticesinde öğretmen yetiştirme konusunda yeniliklerin yapıldığını ifade etmişsir.

Onlara göre öğretmen, karakter eğitimi için uygun ortamı sağlarsa çocuğun karakteri kendiliğinden uygun bir yöne evrilecektir. Karakter eğitiminde öğretmene düşen görev bu uygun ortamı hazırlayıp 
rehberlik etmektir. Fakat araştırmaya dahil edilen eğitimcilere göre bu dönemdeki medrese hocalarının bunu başardıkları söylenemez. Halbuki onlardan beklenen öğrencilerini hurafelerden uzaklaştırıp yaşadığ1 çevrenin ekonomik gücü hakkında bilgi sahibi çalışkan ve vatansever bireylere dönüştürmektir.

Eğitimcilerin Karakter eğitiminde öğretmenin işleviyle en çok ilişkilendirdikleri değerler ise çalışkanlık, sorumluluk ve vatanseverlik değerleri olmuştur. Bu dönemde y1kılmakta olan ülkeyi kurtarabilmek için daha çok çalışmak gerektiği anlayışının hakim olmaya başladığı görülmektedir. Bu anlayışı etkisiyle bu dönemdeki eğitimcilerin eserlerinde çalışkanlık değerine yoğun şekilde yer verdikleri görülmektedir. Çalışkan olmanın temel şartlarından birinin Sağıklı olmak olduğunu belirten eğitimciler, ögretmenlerin bu konuda hassas olması gerektiğini ifade etmişlerdir. Kulak veya gözdeki bir sağllk probleminin tembelliğe yol açma ihtimalinin unutulmaması gerektiğini belirtmişler ve köy öğretmenlerinin yalnızca öğrencileri değil, köylüyü de sağlıklı olmak konusunda bilgilendirmesi gerektiği dile getirilmiştir.

Tembel öğrencileri çalışkan hale getirmek için onların eğilimlerini ve zevk aldıkları şeyleri tespit edip bu yönde çalışmalar yapmasına izin vermek gerektiğini ifade etmişlerdir. Onlara göre başarılı olan çocukların çalışması göz ardı edilerek yetenekli bulunması ve başka alanlara ilgi duyması nedeniyle herhangi bir dersten başarısız olan bir çocuğa tembel denilmesi büyük bir hatadır. Bunun yanında ödül sisteminin yalnızca başarılı öğrenciler için işletilmesi de doğru değildir. Ödül sistemi başarısız olan öğrenciler için de işletilmelidir.

Öğrenciye çalışkanlık bilincinin kazandırılmasında öğretmenin çok önemli bir rolü olduğunu düşünen bu eğitimciler, öğrencinin bazı olumsuz davranışları nedeniyle tembel olarak etiketlenmesinin yanlış bir davranış olduğunu dile getirmişlerdir. Onlara göre, öğrenciyi bu şekilde davranmaya iten ruhi sebepler araşıtıılmalıdır. Tembellik, bir sınav başarısızlığından; yaşanılan çevrenin değişmesinden veya bir arkadaş etkisinden kaynaklanıyor olabilir.

II. Meşrutiyet dönemi eğitimcileri, öğretmenlerin iyi ve etkili bir vatanseverlik eğitimi vermeleri gerektiğini ifade etmişlerdir. Bu beklentinin oluşmasının en önemli nedenlerinden biri o dönemde devletin dağılmasından korkulmasıdır. Farklı etnik grupların ayrı bir devlet kurma istekleri karşısında bu grupların vatanseverlik hissiyatının nasıl artırılabileceği hususunun önemli bir tartışma konusu olduğu görülmektedir. Bu konuda özellikle o döneme kadar ihmal edildiğini düşündükleri tarih ve coğrafya eğitiminin faydalı olacağını düşünmüşlerdir. Onlara göre, çocuktan tanımadığı bir coğrafyayı sevmesini beklemek hatalı olabilir. Bir çocuğun tarihteki fedakârllkları bilmesi onun vatansever olmasını sağlayabilir. Türk'ün (2009, s. 431) II. Meşrutiyet Dönemi Eğitimcisi Satı Bey ve Coğrafja Öğretimi adlı çalışmasındaki bulgular da yapılan bu çalışmanın bulgularını desteklemektedir. Türk, bu çalışmasında, Satı Bey'in öğretmenlerin coğrafya ögretiminde kullanacağı doğru tekniklerle vatanseverlik eğitimine katkıda bulunacağını dile getirdiğini ifade etmiştir. Eğitimcilere göre öğretmen, karakter eğitimi yaparken çeşitli ortamları, durumları ve materyalleri kullanabilir. Örneğin sınıf dış ortamlar, spor karşılaşmaları ve matematik problemleri karakter eğitiminde kullanılabilir. Öğretmenin aile ile işbirliği yapması da karakter eğitimini olumlu yönde etkiler. Ayrıca özel eğitim alan öğrencilere verilecek karakter eğitimi de bu öğrencilerin özel durumları dikkate alınarak yapılmalıdır. Bu sonuçlara dayanarak şu öneriler getirilebilir.

- Bu çalışma 2005 yilında yürürlüğe konan Sosyal Bilgiler Öğretimi Programı'nda yer alan 20 değer ve 12 eğitimci ile sınırlandırılmıştır. Farklı değerler ve eğitimciler üzerinden yapılacak buna benzer çalışmalar ile daha geniş boyutlarda bir sonuca ulaşılabilir.

- II. Meşrutiyet Dönemi eğitim sosyolojisi öncülerinin öğretmenlik mesleğinin karakter eğitimine etkisi ile ilgili görüşleri günümüzde yayımlanan bilimsel çalışmalardaki sonuçlar ile karşıllaştırılabilir.

\section{Etik Beyan}

"II. Meşrutivet Dönemi Ë̆̈itim Sosyolojisi Öncülerine Göre Karakter Eğitiminde Öğretmenin Rolï” başlıklı çalışmanın yazım sürecinde bilimsel, etik ve alıntı kurallarına uyulmuş; toplanan veriler üzerinde herhangi bir tahrifat yapılmamış ve bu çalışma herhangi başka bir akademik yayın ortamına değerlendirme için gönderilmemiştir. $\mathrm{Bu}$ araştırmada doküman incelemesi yapıldığından etik kurul kararı zorunluluğu bulunmamaktadir.

\section{Kaynakça}

Akyüz, Y. (2012). Türk eğitim taribi. Ankara: Pegem Akademi Yayınları.

Atuf, N. (1911). Mektep terbiyesi. Say ve Tetebbu Dergisi, 1(8), 2-8. 
Aydın, Ö.(2008). Sorumluluk ve yardımseverlik odakh karakter eğitimi programmm 7. sinf ögrencilerinin ablaki olgunluk düzeyine etkisi (Yüksek Lisans Tezi). Yeditepe Üniversitesi Sosyal Bilimler Enstitüsü, İstanbul.

Baltacıoğlu, İ. H. (1932). Mürebbilere. İstanbul: İstanbul Sühulet Kütüphanesi.

Baltacıoğlu, İ. H. (1995). Talim ve terbiyede inkılap. İstanbul: Milli Eğitim Yayınevi.

Baltacıoğlu, İ. H. (1938). Toplu tedris. İstanbul: Sebat Basımevi.

Cemil, S. (1911). Ameli olalım. Yeni Mektep Dergisi, 1(3), 65-70.

Cemil, S. (1911). Az ve iyi. Yeni Mektep Dergisi, 1(1), 113-114.

Cemil, S. (1912). Çocukta mesuliyet fikri. Yeni Mektep Dergisi, 1(11), 321-324.

Cemil, S. (1911). İlk muallim kafilesi. Yeni Mektep Dergisi, 2(4), 97-98.

Cemil, S. (1911). Mekteplerimizde meskenet ve çare-i izalesi. Yeni Mektep Dergisi, 1(1), 11-15.

Çam, F. B. (2016). Eğitim sisteminin ortaya çıkışı ve Antik Yunan eğitim anlayışının temelleri. Bartın Üniversitesi Eğitim Fakültesi Dergisi, 5(2), 629-643.

Duran, A. (2017). Meşrutiyet dönemi eğitimindeki yenileşme hareketleri ve cumhuriyet dönemine biraktığı miras. Cappadocia Journal of History and Social Science, 8, 62-77.

Durakoğlu, A. (2014). Gazali'de ahlak eğitimi. Gaæi Eğitim Fakültesi Dergisi, 34(2), 211-226.

Ekşi, H. (2008). Karakter eğitimi. İçinde H. Işılak ve A. Durmuş, Kara tabtayı aşmak öğrenci merkę̧li ögretmenlik. (s. 119121). İstanbul: Edam Yayınevi.

Ekşi, H. (2003). Temel insani değerlerin kazandırılmasında bir yaklaşım: karakter eğitimi programları. Değerler Ĕ̆gitimi Dergisi, 1(1), 79-96.

Ekşi, H. ve Katılmıs, A. (2011). Karakter eğitimi el kitabı. Ankara: Nobel Yayın Dağıtım.

Ersoy, F. ve Şahin, T. (2012). Sosyal bilgiler ders kitaplarının değerler eğitimi yaklaşımları açısından incelenmesi. Kuram ve Uygulamada Eğitim Bilimleri, 12(2), 1535-1558.

Gökalp, Z. (2012). Hars ve medeniyet. İstanbul: Toker Yayınları

Gömleksiz, M. N. ve Cüro, E. (2011). Sosyal bilgiler dersi öğretim programinda yer alan değerlere ilişkin öğrenci tutumlarının değerlendirilmesi. Uluslararası İnsan Bilimleri Dergisi, 8(1), 95-134.

Gövsa, İ. A. (1929). Rubiyat ve terbiye. İstanbul: Devlet Matbaas1.

Kanat, H. F. (1928). Gençlik terbiyesinde ruhi esaslar. Hayat Mecmuası, 4(79), 3-5.

Kanat, H. F. (1934). Muasır terbiye ülkülleri ve terbiye'de yenilikler. İstanbul: Marifet Matbaas1.

Kanat, H. F. (1922). Terbiyenin dâhili teşkilatı hakkında nazariyeler. Düsünce Dergisi, 1(5), 50-52.

Karagöz, S. ve Duman, T. (2014). 1908-1928 yılları arası süreli yayınlarda yer alan eğitim görüşleri ve öneriler. Uluslararası Sosyal Arastormalar Dergisi, 7(35), 576-594.

Karasar, N. (2009). Bilimsel arastırma yöntemi. Ankara: Nobel Yayınc1lik.

Karatay, H. (2011). Karakter eğitiminde edebi eserlerin kullanımı. Turkish Studies, 6(1), 1439-1454.

Katılmış, A., Ekşi, H. ve Öztürk, C. (2011). Sosyal bilgiler ders kazanımlarıyla bütünleştirilmiş karakter eğitimi programının etkililiği. Kuram ve Uygulamada Eğitim Bilimleri, 11(2), 839-859.

Lickona, T. (1993). The return of character education. Educational Leadership, 51(3), 6-11.

Montagu, A. (2000). Cocuklarmız̧a ablaki değerleri Nasıl kaz̧andırabiliriz. (Çev. R. Öncül). İstanbul: MEB Basımevi.

Nami, K. (1916). Çocukluğu sevmek. Muallim Mecmuası, 2(23), 807-810.

Nami, K. (1934). Muallimin meslek ablakr. İstanbul: Devlet Matbaas1.

Nami, K. (1928). Pedagoji önünde gazi. İstanbul: Devlet Matbaas1.

Nami, K. (1932). Terbiyevi yažlar. İstanbul: Matbaacılık ve Neşriyat.

Öztürk, F. (2001). Ethem Nejat Türklük nedir ve terbiye yollar. İstanbul: Kız1l Elma Yayıncilık.

Sat1, M. (1911). Fenn-i terbiye. İstanbul: Kitabhane-i Askeri.

Sat1, M. (1910). Layihalarm. İstanbul: Matbaa-i Hayriyye ve Şürekası.

Sırrı, V. ve Mehmedoğlu, A. U. (2015). Karakter eğitimi: dün bugün ve yarın. Tarih Kültür ve Sanat Araşttrmalar Dergisi, 4(1), 121-144.

Şahin, H. (2012). Osmanlı medreselerinde iktisat eğitimi. Mustafa Kemal Atatürk Üniversitesi Sosyal Bilimler Enstitüsü Dergisi, 9(20), 93-102.

Şahin, M. ve Tokdemir, M. A. (2011). II. Meşrutiyet döneminde eğitimde yaşanan gelişmeler. Türk Eğitim Bilimleri Dergisi, 9(4), 851-876.

Şimşek, H. ve Yıldırım, A. (2018). Sosyal bilimlerde nitel araştırma yöntemleri. Ankara: Seçkin Yayıncılık.

Tural, E. (2007). II. Meşrutiyet döneminde maarif-i umumiyye nezaretinde bürokratik reform. Ankara Üniversitesi Osmanl Taribi Arastirma ve Uygulama Merkezi Dergisi, 31, 177-206.

Türk,İ. C. (2009). II. Meşrutiyet dönemi eğitimcisi Sat1 Bey ve coğrafya öğretimi. Atatürk Üniversitesi Türkiyat Araștırmalar Enstitüsü Dergisi, 16(40), 423-438.

Türker, H. K. (2008). II. Meşrutiyet devri eğitim hareketleri ve günümüze yansımalar (Yüksek Lisans Tezi). Selçuk Üniversitesi Sosyal Bilimler Enstitüsü, Konya.

Ülgen, P. (2010). Geç Ortaçağ'da Avrupa'daki üniversiteler ve bilim. Mustafa Kemal Üniversitesi Sosyal Bilimler Enstitüsü Dergisi, 7(14), 347-372.

Yükrük, S. ve Akarsu, S. (2015). İlkokul (1-4) müzik ders kitaplarında yer alan şarkıların değerler bakımından incelenmesi. Uluslararası Türkģe Edebiyat Kültür Eğitim Dergisi, 4(4), 1684-1707. 


\section{EXTENDED ABSTRACT}

The aim of this research in which the general survey model has been used, is to analyse the opinions of the educators' who emphasize on the sociological aspect of education in the Second Constitutional Period, concerning the role of the teacher in character education. In the choosing of the educators which have been involved in the scope of this research for this general aim, Hilmi Ziya ÜLKEN's book Türkiye'de Cağdass Düsünce Taribi with an extensive content about Turkish Sociology History was benefited from. Furthermore, by also analysing Yahya AKYÜZ's book History of Turkish Education, it was confirmed that these educators were educators who emphasized on the social aspect of education in the Second Constitutional Period. In addition to literature, expert opinions were gathered whilst choosing the educators who have been included in the scope of this research and 12 educators (Emrullah Efendi, Ethem Nejat, Halil Fikeret Kanat, Alaettin Gö̀sa, İsmail Haker Baltacroğlu, Kazım Nami, Nafi Atuf, Prens Sabahattin, Sabri Cemil, Satt Bey, Şemsettin Günaltay, Ziya Gökalp) who've been seen to emphasize the sociological aspect of education in their works were also included in the research.

Collecting the data used in the scope of this research has been done by document analysis method. In the analysing of the documents, the unit of analysis was accepted to be "word". Even though the unit of analysis is accepted to be "Word", it is still not possible to grow away from content in these types of works because every single word can get different meanings in different sentences and paragraphs. Hence, while coding, apart from paying attention to the word, its consistency within that chapter's value was taken into account. Considering the fact that the period being researched is before Republic Period when the language simplification started, the necessity of paying attention to some of the words that are synonyms, antonyms or close meanings of the values' names has surfaced.

The data collected by using the document analysis method were resolved by using descriptive analysis approach. In descriptive analysis method, the aim is to present the collected data to the readers by editing and interpreting them. Data that's been collected with this aim were systematically and openly described, then with these descriptions made, they were interpreted and some results under the title of discoveries were reached. At the same time, in this work, in accordance with the descriptive analysis approach, 20 values that appeared in 2005 Social Studies Lesson Curriculum of Ministry of National Education were used for the analysis.

İbrahim Alaettin Gövsa, Kazım Nami and Sabri Cemil were seen to be the educators who emphasized on the function of teacher on character education the most, amongst all the educators who highlighted the social aspect of education during the Second Constitutional Period. İbrahim Alaettin Gövsa was the educator who had mentioned the function of teacher most often. Gövsa expressed that a teacher needs to examine a child thoroughly before reaching a decision.

According to these educators, if a teacher sets up a proper environment for the child's character education, the child's character will evolve in a suitable direction on its own. The duty upon a teacher in character education is to prepare this environment and guide. However, according to the educators that were involved in the scope of this research, it can't be said that madrassa teachers in this period succeeded in that. Whereas, what is expected of them is to get their students away from superstitions, turn the students into hard-working and patriotic individuals that have information about the environment's economic power in which they live in.

The values in character education which the educators associated with the function of teacher the most were industriousness, responsibility and patriotism. In order to save the country that was collapsing during this period, it can be seen that the understanding of the need to work more started dominating. With the effect of this understanding, it is seen that educators in this period intensely gave place to the value of industriousness in their works. Educators who indicated that one of the essential conditions of being hard-working is being healthy, have expressed that teachers need to be sensitive about this. They expressed it shouldn't be forgotten that the possibility of a health problem of ears or eyes can cause laziness and mentioned that village teachers should inform not only the students but also the villagers of being healthy.

They expressed that, to get lazy students to be hard-working, it is needed to determine their tendencies and the things they enjoy and allow doing studies in this regard. Finding children talented who are in their opinion considered to be successful students regardless of their studies and calling a child who is 
academically unsuccessful because of their interests in other fields, is a big mistake. It is also not true to run reward system only on successful students. Reward system should also be run for unsuccessful students. If such a method is followed, education of justice will also be given to the students implicitly. Meanwhile, it will also contribute in making up the deficiencies in the industriousness and self-confidence of students who are considered to be unsuccessful.

These educators who think that teachers have a very important role in raising awareness about industriousness in students, also pointed out that it is wrong to tag a student as lazy just because of a few of their negative behaviours. According to them, psychological reasons which push the students into acting like this should be investigated. Because laziness might be derived from an exam failure, changes of living environment or a friend influence.

Pioneers of the Second Constitutional Period sociology of education expressed that teachers need to give a good and efficient education on patriotism. The most important reason as to why this expectation arose was the concerns regarding the disintegration of the state. It can be seen that there is an important argument on how to increase the feeling of patriotism on different ethnical groups in the face of their desires to form a separate state. On this topic, they thought that giving history and geography education which they thought has been neglected up until that period of time would be beneficial. According to the educators, teachers can use various environments, situations and materials for character education. For instance, non-class environments, sports matches and mathematical problems can be used for character education. Teachers cooperating with families also affect character education in a positive way. Moreover, the character education of special education students should be done in its own way. 